\title{
Heterotopic Place-Making in Learning Environments: Children Living
as Creative Citizens
}

Construcción de heterotopías en ambientes de aprendizaje: los niños viviendo como ciudadanos creativos

Research Article | Artículo de investigación

Received on: July $10^{\text {th }}, 2020$ Accepted on: February $15^{\text {th }}, 2021$ Available online from: February 2021

doi: 10.11144/Javeriana.m14.hpml

Cynthia Yael Adlerstein-Grimberg cadlerst@uc.cl

Pontificia Universidad Católica de Chile, Chile ORCID: https://orcid.org/0000-0001-7174-0100

Andrea Bralic-EcheVerría abralic1@uc.cl

Pontificia Universidad Católica de Chille, Chile ORCID: https://orcid.org/0000-0001-5447-9449

To cite this article | Para citar este artículo Adlerstein-Grimberg, C. Y. \& Bralic-Echeverría, A. (2021). Heterotopic place-making in learning environments: Children living as creative citizens. magis, Revista Internacional de Investigación en Educación, 14, 1-36. doi: 10.11144/Javeriana. m14.hpml 


\section{Abstract}

This paper reconceptualizes children as already-beingcitizens within kindergarten learning environments. It draws on Foucauldian heterotopology to show what type of heterotopias entangle two and three-year-old in everyday place-making practices and how they empower themselves to inhabit learning environments as creative citizens. After a collaborative ethnographic immersion in 16 Chilean public kindergartens during the academic year 2019, findings show three types of heterotopic place-making that enact children's citizenship: Unpredictable movements and wanderings, new ruling artifacts, and serendipitous spatial transgressions. We discuss how these unsettle ECE learning environment utopias and invite teachers' improvisatory practices for alternative spatialities and children's creative citizenship.

\section{Keywords}

Citizenship; children; early childhood education; heterotopias; place-making; learning environments

\section{Resumen}

Este artículo ofrece un análisis acerca de cómo los niños y niñas son ciudadanos y ciudadanas activos dentro de los ambientes de aprendizaje del jardín infantil. El artículo se basa en la heterotopología foucaultiana para mostrar qué tipo de heterotopias establecen los menores de dos y tres años en sus prácticas cotidianas de creación de lugares y cómo se empoderan para habitar ambientes de aprendizaje como ciudadanos creativos. Después de una inmersión etnográfica colaborativa en 16 jardines infantiles chilenos de caracter público durante el año académico de 2019, los hallazgos muestran tres tipos de creación de lugares heterotópicos que promulgan la ciudadanía activa de niñxs: movimientos y exploración de los lugares de forma impredecible, nuevos artefactos dominantes y transgresiones espaciales fortuitas. En el presente artículo discutimos cómo se dan estas utopías no marcadas del espacio de aprendizaje de educación preescolar e invitamos a las prácticas de improvisación de Ixs maestrxs para espacialidades alternativas y la ciudadanía creativa de menores de 2 a 3 años.

\section{Palabras clave}

Ciudadanía; niño; educación de la primera infancia; heterotopías; lugar; ambientes de aprendizaje 
Article description | Descripción del artículo

Research article derived from the project Servilization of the MAFA System for public kindergartens in the national territory: Implementation of pedagogical communities based on the modeling of the physical learning environment, FONDEF code IT14I10120, and the MAFA to JUNJI Licensing Agreement (2018-2022).

\section{Introduction}

This paper points out a posthumanist view of early childhood education (ECE) citizenship, in which children's heterotopias or unexpected creation of 'other spaces' (Foucault, 1986) than those given within the kindergarten, enact authentic participation in a shared community and a more-than-human world (Hackett \& Rautio, 2019). We reconceptualize the relationship between two and three-year-old entanglement with the world and their lived citizenship through place-making by drawing on Foucault's heterotopology. Our primary purpose is to show how through different types of heterotopic place-making or original 'spaces of alternate ordering,' children assume an agentic role as 'already citizens' (Bath \& Karlsson, 2016). We discuss how they engage in meaning-making to negotiate learning spaces in everyday kindergarten life and describe how heterotopias enable them to share the learning environment's authorship and live as creative citizens (Hargreaves \& Hartley, 2016b).

Children's heterotopic place-making in the kindergarten is a 'lively entanglement' (Hohti, 2016) or 'human and non-human interplay' (Nordtømme, 2012) of agentic activities that produce new realities. However, these new places children make for learning and living are like counter-sites, where "the world is simultaneously represented, contested, and inverted" (Foucault, 1984, p. 9). Heterotopias are places that mirror, distort, unsettle, or invert the spaces children live in and by (Charteris et al., 2017). So from a Foucauldian lens, we observe heterotopias express children's citizenship because they are "places of resistance within the normalized" (Foucault, 1984, p. 178) that position themselves as meaning-makers. Albeit these heterotopias often go unrecognized by ECE teachers or might be considered challenging behavior, children naturally involve in the co-creation of places and instinctively participate with others to build inter-generational knowledge (Devine \& Cockburn, 2018; Murris, 2016, 2017b) that approaches vital issues of their communities (Xu, 2020). Hence, from a heterotopology understanding, children are citizens when making places in the kindergarten as 
"response-able subjects with potential to bring new ideas into the learning processes and build acts of togetherness" (Bath \& Karlson, 2016, p. 560).

Our citizenship stance grounds on a posthuman premise (Hackett \& Rautio, 2019; Murris, 2016, 2017b). It acknowledges children as relational and entangled (Hohti, 2016; Hacket \& Rautio, 2019) competent meaning-makers with their own voice. In other words, our understanding of the 'competent' child-citizen shifts from developmental skillfulness to portraying them as "social actors in their own right" (Lindgren, 2020, p. 922). In posthuman ECE, children and "all earth-dwellers are equal - they are mutually entangled, always becoming and always intra-acting with everything else" (Murris, 2017b, p. 193). We argue kindergarten is not a (developmental) stage to become a qualified citizen. Instead, ECE centers are environments of quotidian encounters where children live and learn citizenship as society members.

The posthuman child as a citizen is not only discursive but also material. In taking the material turn of posthumanism (Murris, 2016, 2017a; Myers, 2015), we are critical of human-centeredness that binarizes learning environments into adult or child-centered (Jobb, 2019), dismissing agentic entangled forces of the material world that children are part of. We weave together Reconceptualist pedagogies (Jobb, 2019; Moss, 2017; Ryan \& Grieshaber, 2005; Pacini-Ketchabaw et al., 2016) and critical children's geographies (Duhn 2012; Hackett et al., 2015; Nairn \& Kraftl, 2016) to approach the distinctiveness of space, place, and children's heterotopolgy (Foucault, 1984; MacRae, 2011; Wild, 2011). On this track, our monistic onto-epistemology claims that children's lived citizenship is produced in everyday creative entanglements of heterotopic place-making, where they are equal dwellers of the world and always-already citizens (Hohti, 2016; Murris, 2017a).

Our new citizenship approach displaces the traditional definitionof status (Xu, 2020). It is reluctant to think that civic engagement develops future smart-productive citizens and accepts an exercise of future-building citizenship (Baker, 2013; Millei, 2009). This position also movesaway from active citizenship in ECE classrooms (Baker, 2013), which encourages membership and civic participation by having children do assignments to become rather than being-citizens here-and-now. We turn towards an understanding of citizenship that lies in the mundane but powerful ways by which children share authorship of place-making within the learning environment and the resourceful ways they navigate the yet adult-centered world of the kindergarten to achieve cooperative initiatives based on voluntary association (Millei \& Imre, 2015). In doing so, we point-out how children permanently engage in co-constructing learning environments, less as consumers of 
staged layouts or spatial pedagogical solutions and more as authors of meaningful places (Cortés et al., 2020).

In Chilean ECE, there is much rhetoric on children's citizenship, rights to social participation in matters that affect them, and quality education involving access to high-standard learning environments (Adlerstein et al., 2018; Andrade, 2017). As in other countries, the concept of children's citizenship appears widely supported and unproblematic in ECE policies (Marsh et al., 2018; Millei \& Imre, 2016; Stephen \& Gadda, 2017), especially since 2018 that the Chilean National ECE Curriculum introduced 'Living Together and Citizenship' as one of the eight learning nuclei (Mineduc, 2018). However, its pedagogical concretion in public kindergartens drags timely ambiguous understandings and inherent tensions between childhood viewed as becoming and acquiring citizenship or children as 'citizens in the making' (Marshall, 1950) and 'already-being' or 'living as citizens' (Phillips \& Moroney, 2017; Xu, 2020). The national framework inscribes citizenship within the ambit of 'Personal and Social Development' where it defines 'appropriate children's protagonism,' 'democratic and positive coexistence,' and presents practical guidelines for "human rights exercise, collaboration and respect in the classroom" (Mineduc, 2018, p. 46). As for Bath \& Karlson (2016), we find the ECE Chilean view of citizenship positions children "in need of induction or socialization into a real adult version of citizenship" (p. 556). So, albeit citizenship is not a new approach in our Chilean ECE, this version where teachers consult young people but do not acknowledge thembeing-citizens in the present sharply contrasts with our creatively lived citizenship framework through heterotopic place-making.

We make the case of a Chilean ECE public network of 16 kindergartens inspired by Reconceptualist ideas of learning environments and children as being-citizens. For the last eight years (2012-2020), the community has been implementing the MAFA System (Adlerstein, 2017; Adlerstein et al., 2018) that unfolds co-created learning environments and pedagogies of place (Gruenewald, 2008; Theobald, 2018). Our inquiry examines the MAFA-community's pedagogical documentation to unveil how, in these kindergartens, children entangle with humans and non-human to raise surprising heterotopias and live as creative citizens that mitigate physical and symbolic constraints.

The article contributes by foregrounding a new understanding of citizenship in public kindergartens. We unsettle the taken-for-granted ECE learning environments that control children within utopic stable spaces and standard playful resources to acquire citizen skills. At the same time, we show how, within MAFA learning environments, children live as unbound creative citizens rather than a predetermined map (Olsson, 2017) of 
evolving autonomy and citizenship. It turns straightforwardly to the heterotopic place-making two and three-year-old achieve destabilizing adult pedagogical utopias and social constraints. As a heterotopia itself, this article does not escape the dominant Chilean ECE citizenship discourse. Instead, it engages with its policy, as Moss posits, wanting to "provoke debate about different or 'real utopias' and how they might be achieved" (Moss \& Moss, 2018, p. 6).

\section{Theoretical Framework}

\section{ECE Learning Environments in the Key of Space, Place, and Place-Making}

An intense debate on early childhood's learning environments is emerging, along with a plethora of innovative experiences where ECE teachers struggle to create stimulating learning environments (Adlerstein, 2017; Cortés et al., 2020; Cavallini et al., 2017; Hackett \& Rautio, 2019; MacRae et al., 2018; Marsh et al., 2018). Though research approaches and philosophical stances widespread into opposed assumptions, there is ample consensus on learning environments as creators of children's possibilities for interaction, participation, and meaning-making (Hohti, 2016; Nordtømme, 2012). Likewise, the diverse fields researching ECE learning environments acknowledge they embed values, expectations, and rudiments that may also open up exclusion possibilities (Könings et al., 2017a; Robson \& Mastrangelo, 2018). Thus, ECE learning environments have become a shared challenge for policymakers and researchers when facing unequal childhoods and strengthening positive lives (Könings et al., 2017a; Mahat et al., 2018; Robson \& Mastrangelo, 2018).

The approach to learning environments is not clear-cut. Diverse research positions inform policies and tension pedagogical practices within ECE centers. At the ends of the spectrum, views either follow a quality discourse or a meaning-making narrative in ECE (Dahlberg et al., 2007). The Developmentalists, from environmental psychology and pediatrics, demonstrate how high-quality standard environments successfully support learning and holistic development (Melhuish et al., 2016; Shonkoff, 2010; Sylva et al., 2006). They argue that "children develop only as environment demands development" (Shenk, 2015, p. 35), focusing on given layout arrangements for children and post-occupancy evaluation of settings. On the other hand, Reconceptualist pedagogues from socio-constructivist positions stress that learning environments are a co-construction between children, family, and educators. They contest standardized designs based on stable learning centers and advocate for what Malaguzzi called the third 
teacher (Hoyuelos, 2005; Rinaldi, 2012). This understanding of the learning environment rises from relational pedagogies (Dahlberg et al., 2013) and on-going place-making that listens to children's voices in everyday life (Miller, 2019; Robson \& Mastrangelo, 2018; Strong-Wilson \& Ellis, 2007; Wood et al., 2015). Though this view developed in the Italian preschools of Reggio Emilia, it accomplished great recognition worldwide, becoming the postmodern paradigm of learning environments in ECE (Biroli et al., 2017; Cortés et al., 2020).

Recently, a Posthumanist philosophical perspective bursts into this spectrum to challenge the pedagogies of Reconceptualism and human-centered learning environments. It claims a material turn that attributes agency to the material world and upbrings the ignored forces of things and how 'matter matters' (Murris, 2017a, p. 193). Posthuman learning environments decenter human subjects and give "greater attention on how encounters with material objects deeply implicate in the emergence of meaning" (MacRae et al., 2018, p. 507). In doing so, learning environments become lively and playful entanglements where children, materials, sensations, and spaces lose ageist boundaries to co-exist at once (Hohti, 2016; Procter \& Hackett, 2017).

Despite the debate between perspectives, there is some relevant consensus on shaping ECE learning environments. Firstly, they do not restrict to designing physical architecture, rearranging classrooms (Cardellino et al., 2017), or solving 'just space' issues (Robson \& Mastrangelo, 2018). ECE learning environments include and intertwin social, cultural, temporal, physical (built and natural), and virtual aspects (Blackmore et al., 2011; Miller, 2019). Though learning environments' research is often inquiring for influence on early learning outcomes (Duarte et al., 2017), the relationship is complicated, and the evidence is inconclusive. Secondly, there is pedagogical value in seeking teachers' and children's points of view in the learning environments design process and in acknowledging the capability of young people to influence with their opinions in matters that affect them (Könings et al., 2017; Miller, 2019; Woolner et al., 2018). Third, the learning environment holds educational opportunities and communicates underlying pedagogical values and beliefs that may be obstacles or supporters of a shared sense of ownership amongst users of settings (Miller, 2019; Organisation for Economic Co-operation and Development, 2017; Woolner et al., 2012).

We argue these widely accepted understandings on learning environments (with a greater or lesser emphasis on human agency), based on the renowned spatial turn of social sciences (Foucault, 1998). It brings into ECE a more critical understanding of power relations in children's spatialities (Jobb, 2019) that encounter and juxtapose in settings and pedagogy. 
Spaces allude to the physical and material world, the three-dimensional environment where curricular events occur, and where objects have position and direction. While places, stress spaces invested with meanings and attributed with understandings of social possibilities and cultural appropriateness by those who inhabit them. Thus, we humans and non-humans are located in a heterogeneous landscape of spaces but entangle to act in and produce places (Foucault, 1984; Jobb, 2019), hence engaging in place-making.

This crucial distinction of the spatial turn in ECE has been extensively studied (De Coninck-Smith \& Gutman, 2004; Edwards et al., 1998; Jobb, 2019), particularly in center-based programs and urban out-door environments. The interdisciplinary body of research is expanding on 'place-attuned pedagogies' (Hong et al., 2017; Miller, 2019; Strong-Wilson \& Ellis, 2007) 'emplaced entanglements' (Hohti, 2016; Hacket \& Rautio, 2019; MacRae et al., 2018), 'place-conscious education' (Gruenewald, 2008; Mills \& Comber, 2013), and 'place-based pedagogies' (Cavallini et al., 2017; Franz, 2019; Gruenewald, 2003; Mahat et al., 2018; Organisation for Economic Co-operation and Development, 2009, 2017). They agree to distinguish and attach space and place to meaning-making, situating place-making in the core of learning environments and pedagogies. This work sets learning environments as complex socio-spatial assemblages (Dovey \& Fisher, 2014) that emerge from creative negotiations of spatial access and control.

\section{Heterotopias or 'Other Spaces' of Children's \\ Place-Making in the Kindergarten}

The space-place sensitivity and place-making in ECE settings have become a conspicuous alternative narrative (Moss, 2017, 2018b) about learning environments. Though Foucault did not analyze spatialities in early childhood educational contexts, his work serves as an insightful reference for diverse researchers (Jobb, 2019; Mac Naughton, 2005; Taylor \& Richardson, 2005), inquiring about place-making of 'other spaces' (Foucault, 1984) in kindergartens and urban environments. From a Foucauldian lens, 'other spaces' refer to counter-sites that invent new relations to contest or invert social life's real spaces. He refers to two types of 'other spaces': Utopias and heterotopias. Whereas utopias are unreal, fantastic, and perfected spaces (that do not have a real site), heterotopias are real locations that exist like contesting places, simultaneously talking about, disputing, and overturning conventional spaces (Foucault, 1984; MacRae, 2011; McNamee, 2000). Contrastingly, heterotopias oppose utopias because they are practical emplacements or enacted utopias, and though they escape dominant power relations and social tensions, they are localizable sites within quotidian lives. 
Taylor \& Richardson (2005) exemplify both utopias and heterotopias with a queer perspective observation of children's dramatic play in a kindergarten home corner. They show its stylized façade, colors, miniaturized furniture, and artifacts as a pedagogical utopia of "heteronormative domestic order and developmental appropriateness, embeded in the architecture" (Taylor \& Richardson, 2005, p. 164). In doing so, they expose how staged spaces and corners frame dominant pedagogical utopias and the early childhood orthodoxies that support them. Their work continues into how children's heterotopias disrupt the domestic-play home corner utopia and reshuffle its ordering and thinking by raising a 'risky police station' and a 'royal stable drama of heroic princesses and naughty ponies.'

We follow the authors' research to argue that when children use ECE teachers staged landscapes as expected, they enact or inhabit the teachers' pedagogical utopias (Gosling, 2014). However, when teachers allow and entangle with children's unintended place-making of counter-sites and extend the spatial discontinuities or alterities, they create heterotopias to reconceptualize kindergarten and society's factual spaces and orderings (Palladino \& Miller, 2015). Here lies the highest relevance of heterotopias for us: They are a specific type of place-making that position children and adults as equal dwellers of learning environments and social everyday lives. Drawing on heterotopology (Foucault, 1984, 1998), we coin the notion of heterotopic place-making to introduce this alternative way of making places in everyday kindergarten life. We claim it entangles children, adults, and things in agentic experiences that set-apart adult-given spaces and build new places of alternate ordering. Heterotopic place-making emerges fortuitously (in Foucauldian words by 'serendipity') within the learning environment, suspending assumed behavior norms. It triggers relations that escape the imposed system of values to interrupt the naturalized social flow of learning and living.

In our opinion, not all place-making within ECE learning environments and settings have a heterotopic onto-epistemology. There is an expanding body of literature on children's multimodal emplaced meaning-making (yet non-heterotopic) that illustrates the on-going flow of lively entanglements in kindergartens, such as 'running and spinning around a big old pine tree' and 'grass-hill-rolling' (Hackett \& Rautio, 2019). However, children's heterotopic place-making adds a disturbing nature that unsettles and enacts different relations and understandings about everyday life. In Foucauldian words, heterotopic place-making has the "curious property of being in relation with all the other sites, but in such a way as to suspect, neutralize, or invert the set of relations that they happen to designate, mirror, or reflect" (Foucault, 1986, p. 3). Contrastingly to the plethora of posthuman 
examples (Cortés et al., 2020; Hackett et al., 2017; Hackett \& Somerville, 2017; Hohti, 2016), this type of place-making inverts the spaces children live in and by (Charteris et al., 2017). It unfolds as "places of resistance" (Foucault, 1986, p. 178) that create new realities within the kindergarten's normalized spaces.

Foucault argues children are familiar with heterotopic place-making because, through their play, "in the attic, the garden or their parents bed, they find the ocean, the sky or the Wild West" (Foucault \& Faubion, 1998, p. 181). In this regard, heterotopology could be expected a vast study field reconceptualizing early childhood learning environments, but published work shows the opposite. Within pedagogies and childhood critical studies, it is yet evolving and much less approached than children's agency, play, and participation. The scarce research in ECE settings acknowledges heterotopias in children's everyday lives and accounts for how imagination enables them to resist and escape control (McNamee, 2000). Inquiries contest the trivialization of young people's creative productions', mainly by foregrounding heterotopic place-making in their artwork (Atkinson, 2002, 2012; MacRae, 2011) and urban spaces (Kernan, 2010). Heterotopology also developed a strong stance in linking play and power distribution in diverse ECE learning environments like the classroom (Adlerstein, 2017; Wild, 2011), museums (Hackett, 2015; MacRae et al., 2018), playgrounds (Pitsikali \& Parnell, 2019), learning corners in kindergartens (Taylor \& Ricardson, 2005) and libraries (Radford et al., 2015). All this body of work agrees on showing the juxtaposition of segregated spaces of protected leisure and learning for children; at the same time, they operate as children's places of playful denunciation.

\section{Children's Heterotopic Place-Making \\ as Creative Citizenship Enactment}

Heterotopic place-making in the kindergarten comprises children's 'creative citizenship' (Hargreaves \& Hartley, 2016a; Marsh et al., 2018) because they enact "places of resistance within the normalized" (Foucault, 1984 , p. 178), opening to diverse forms of collaboration, invention, and social expression (Hargreaves \& Hartley, 2016b). However, this understanding of young children as being-citizens, now rather than as becomings and in-waiting citizens, is a recent internationally emerging field in ECE research (Larkins, 2014; Marsh et al., 2018; Xu, 2020). A broad consensus accuses the lack of good-quality studies on citizenship pedagogies in early years. It also points out the need to deepen understanding of positive children's citizenship, drawing on empirical inquiry that considers their 
perspectives and agencies (Patterson \& Kocher, 2018; Millei \& Imre, 2009; Stephen \& Gadda, 2017).

Larkins' inspiring work on citizenship draws on critical realist theory to show how children's views are mostly absent, particularly those under 13 years, to the point of facing structural discrimination (Larkins, 2016). Similarly, in their ECE review, Stephen \& Gadda (2017) suggest that young children are excluded from citizenship debate due to their perceived immaturity and lack of capacity. Bath \& Karlsson (2016) accord and call attention to children as the ignored citizen, as Devine \& Cockburn (2018) foreground young people's invisible lived contributions. Furthermore, Millei \& Imre (2016) observe how children's unreasonable or incorrect views delegitimize young people's lived citizenship. Summarizing, state of the art is emphatic in demanding awareness on the (im)possibilities of children's citizenship embedded in curricular policies and pedagogical discourses (Archard \& Archard, 2019; Devine \& Cockburn, 2018; James, 2011). Especially in current times, when neoliberal reforms assume citizenship as a socio-political status (Hargreaves \& Hartley, 2016a) that grants several rights, specific expectations, and obligations, "with the potential to both include and exclude children" (Stephen \& Gadda, 2017, p. 26).

In recent years, Reconceptualist and Posthuman research have come out to challenge traditional conceptualizations of children's citizenship, defined upon an ageist nation-state status and bounded to the fulfillment of republican responsibilities and obligations. Early childhood studies and alternative pedagogical research are turning towards models of 'inclusive citizenship' (Lister, 2007), 'lived citizenship' (James, 2011; Warming \& Fahnøe, 2017) and 'creative citizenship' (Hargreaves \& Hartley, 2016a), where children are already being-citizens (Bath \& Karlson, 2016), active contributors in the present $(\mathrm{Xu}, 2020)$, and committed in social citizenship processes (Devine \& Cockburn, 2018).

These new understandings conceive citizenship as an embedded practice in everyday agencies (James, 2011) that contribute quotidianly to interdependent social relationships (Larkins, 2014, 2016). For example, Larkins' study with marginalized children in Wales and France shows different ways children act as interdependent citizens in the mundane "making of rules for social existence" (Larkins, 2014, p. 7). Similarly, Devine \& Cockburn (2018) recognize a fluid and evolving citizenship practiced by migrant children in UK schools that bring inter-generational solidarity practices and places to mobilize social and cultural capital. They describe children's 'language translations,' 'caring work,' and 'stories of safeguarding family reputation' as agencies that escape social welfare. It is notable 
how emerging citizenship research is putting special attention to children's politics of space and alternative place-making claiming that their creativity and thought-provoking practices of everyday life (Millie \& Imre, 2016) are the core of today's children's citizenship.

Within this framework, we argue that heterotopic place-making is a valuable analytical tool to reconceptualize children's enactment of creative citizenship. In doing so, we propose understanding our object of study as everyday-citizen-heterotopias. By scrutinizing children's spatial empowerments in learning environments and the heterotopic place-making that unfolds, we deepen the understanding of a lived citizenship that positions their perspectives and themselves as 'already citizens' (Bath \& Karlsson, 2016). We highlight that within heteropology, children do not have citizenship by default, as they do or don't in traditional perspectives of citizenship (classic liberalism and civic republicanism). Instead, they gain agency and live their citizenship (Esser, 2016) through heterotopic place-making. In these terms, children's heterotopic place-making unbound them to inhabit new worlds, and negotiate other possible realities as creative citizens (Hargreaves \& Hartley, 2016a), and live as heterotopians (De Cauter \& Dehaene, 2008).

Creative citizenship emerges through mainstream European and American communitarian thinking in center-left and center-right politics around the millennium's turn (Hargreaves \& Hartley, 2016). Its research in young children's learning environments is very recent and more developed in educational projects that contest neoliberal approaches of becoming-citizen $(\mathrm{Xu}, 2020)$. Compared to other similar narratives, the main contribution of creative citizenship in ECE is it brings-in imaginative entanglements that make places with no conscious civic intent (Hargreaves \& Hartley, 2016b; Marsh et al., 2018), but voice and influence togetherness and social life. We argue that creative citizenship unfolds intuitively through heterotopic place-making, in the same way that heterotopia itself is a lucky finding that emerges by serendipity (Foucault, 1986, 2001). Creative citizenship is neither intended by children nor planned by teachers, instead, it fosters agency of ingenious encounters, and a lived citizenship (Procter \& Hackett, 2017) "with emphasis on their liberatory and emancipatory potential" (Marsh et al., 2018, p. 3).

The most prominent example of creative citizenship in ECE learning environments is the Maker Spaces in the Early Years Project — better known as the MakEY Project-, and part of the Maker Movement (Marsh et al., 2018). The MakEY project is currently an expanding consortium located across Norway, Finland, Iceland, Denmark, Romania, UK, and the USA. Its Makerspaces implement learning environments for "critical making" in 
very diverse settings (from classroom areas in kindergartens to high-tech fabrication labs), where children and adults encounter to develop ideas of universal benefit that materialize in some kind of physical or digital form. Interestingly, they posit maker citizenship "which draws together understandings of making, digital literacies, and creative citizenship" (Marsh et al., 2018, p. 1).

Similarly, the Reggio Emilia pedagogical philosophy, which internationally expanded children's engagement in co-creating the third teacher, also unfolds creative citizenship. We argue that its understanding bases on a human-rights notion of citizenship (Sounoglou \& Michalopoulou, 2016) that approaches space and place politics of children acknowledging kindergarten's right to designing its own environment (Hoyuelos, 2005) and children's right to grow, learn and inhabit aesthetically beautiful and provoking spaces. Though Reggio Emilia aims for deep responsiveness to children's multimodal expressiveness - the 100 languages of children- (Wood et al., 2015), it presumes human-centered environments where children flow and dwell thought-provoking designed spaces and relational pedagogies (Edwards et al., 1998; Gandini, 2011). In our opinion, from a Foucauldian politics of space, the third teacher is a robust pedagogical utopia. Still, we do not find a citizenship perspective based on children's contestant place-making and non-human agency. Furthermore, the current state of the art does not show a Reggio-critical position on the evolving understandings and sorts of children's citizenship presented by policies, kindergartens, and schools.

On the same track that MakEY settings and Reggio schools, the MAFA project is developing innovative learning environments in Chilean urban public kindergartens (Adlerstein, 2017; Adlerstein et al., 2018). Drawing on relational and lived-citizenship principles, it brings place-based pedagogies into the classroom through a system of physical and digital resources. In doing so, ECE teachers and children inhabit kindergarten's (given) spaces and enact citizenship when entangling and negotiating place-making in new, risky, and surprising ways. The MAFA system builds on three components: Wooden artifacts that replace traditional furniture, a modeling device that enables children to project and prototype their learning places, and an application (MAFApp) that creates an online community for ECE teachers to share pedagogical documentation of children's place-making.

Although MAFA's beginnings contested Chilean neoliberal curricular and architectural policies for their narrow understandings of ECE learning environments, it has thrived to influence new frameworks. In 2018 the new National ECE Framework (Mineduc, 2018) introduced "Togetherness and Citizenship" as a learning nucleus, based on MAFA's conceptual model of 
negotiated learning environments and children's creative citizenship. Also, its influence extended to establishing new spatial standards and regulations for kindergartens' spaces and materialities. Both upgrades represent relevant turns of Chilean ECE orthodoxies that partly build on MAFA's vanguardist research and innovative advances in public and private ECE settings (Adlerstein, 2017; Mineduc, 2019).

\section{Methodological Framework}

\section{A Post-Qualitative and Collaborative Ethnographic Approach}

Our study explored children's enactment of citizenship through heterotopic place-making, inside kindergartens, with a post-qualitative approach (Lather \& St. Pierre, 2013; St. Pierre, 2019). This interpretative framework is highly relevant in ECE's current performative culture (Falabella, 2014; Moss et al., 2016). Quantitative research of cost-benefits on quality ECE spaces abounds (Burney \& Claflin, 2016; File, 2012), the same as qualitative inquiries that evaluate learning environments to generalize teachers' best practices (Cortés et al., 2020; Fors et al., 2013). But there is little inquiry on the creative agency (Shonkoff, 2010), enabling children's lived citizenship, and research to acknowledge fortuitous heterotopias as mechanisms of sharing learning environments' authorship. The pressure of accountability and productivity pushes pedagogical researchers and practitioners into convenient and controllable studies that leave little room for methodological improvisation and serendipity (Moss, 2018a; Pyyry, 2016).

Post qualitative inquiry allowed us to reconceptualize ECE pedagogical binarized views and curricular normative citizenship by living theories in experimentation and contact within the real (St. Pierre, 2019). Like other post-qualitative researchers, our experimental fieldwork had a long unfolding of 13 months between March 2019 and May 2020. It encompassed "risky, creative, surprising and intense experimentation focused on things in the making" (St. Pierre, 2018, p. 604), instead of things already-made, as in traditional qualitative methodologies.

Following critical and collaborative ethnographers (Hackett et al., 2017; Lassiter \& Campbell, 2010), we understood the process as an inquiry along with children, ECE teachers, and assistants in the role of dialogic partners, to maintain their "authentic participation" (Miller, 2019). We intended to reflexively offset colonial modes of research by engaging with them along the whole process. As Pink (2008), our collaborative ethnographic design embodied experiences of making and understanding the heterotopias we pursued to analyze. The fieldwork unfolded as a collaboration in the making (Pink, 2008) with shared-walking conversations about children's 
place-making, participation in online pedagogical documentation about children's spatial conquests and transgressions, and communal fieldnote writing with adults about children's key socio-spatial assemblages and emergent incidents within their learning environments). We found Pink's call to attune with people's emplaced practices interestingly challenging in children's studies but tremendously consistent with the posthuman and post-qualitative research of heterotopic enactments of citizenship.

\section{MAFA-Community as a Unique Case and the ECE Participants}

We make the unique case of a Chilean ECE public network of 16 kindergartens, inspired by post-foundational ideas (Moss, 2018b) of learning environments and children as creative citizens. MAFA community is the only public ECE network in Chile materializing a pedagogical narrative about children being entangled co-creators and inhabitants of their kindergartens (Adlerstein, 2017). Our criteria to consider it a unique case based on their exceptional circumstance of being highly recognized for unfolding pedagogies of place and lived citizenship in disadvantaged urban contexts, despite neoliberal educational regulations (Programa de las Naciones Unidas para el Desarrollo, 2017). All this configuration forms the unique Chilean case of an "ECE edge community of practice," where different voices, practices, and understandings entangle searching for new and creative ways to build place-based practices (Clark, 2019).

The first two months of ethnographic immersion (during the academic year 2019-2020) focused on establishing research rapport with ECE personnel and key stakeholders (Miller, 2019; Woolner et al., 2012) and tackling people's professional desirability and ideas of learning environments as fixed and tidy settings. Likewise, demonstrating that we were unusually interested in children, ECE teachers, and assistants as our key collaborators to co-construct narratives and stories about their place-making and citizenship. At first, adult participants were cautious in their doing, thinking, and acting (Ferrare \& Apple, 2010). Then, when we did not put enthusiasm in the products they achieved and showed but enjoyed their mundane details of the process and the place-making stories they walked-us through, we found authentic collaboration and the best moments of data production-analysis.

From that twisting point on, we counted with the active participation of 82 ECE classroom teachers and assistants, 17 supervisors, 425 two and three-year-old, and 16 kindergarten principals. Though participants belong to different regions of the country, and their settings vary enormously in sociocultural backgrounds, we consider them all part of the MAFA-case and not as individually representative of kindergarten-cases. 


\section{Data Set of Documented Heterotopias and Abductive Analysis}

The production and analysis of data in this research process were entangled and emplaced as the study object. As St. Pierre claims (Lather \& St. Pierre, 2013; St. Pierre, 2019) about her post-qualitative inquiries, data, and data analysis always appeared to her after official fieldwork, in the same way, MacRae et al. (2018) build a set of "sticky data" from many years of different research projects about children in museums. Building our dataset also involved an analysis process where "scrutiny of evidence depended, in part, on researchers' responses to happenings beyond the study" (Earl-Rinehart, 2020, p. 2). So encompassing the fieldwork, we carried out an abductive analysis process of deliberate moving back and forth from the task of scrutinizing (Bryant et al., 2019) textual, visual, and experiential data. Our final dataset draws upon 441 pedagogical documentations narrating children's place-making in their kindergartens, 87 communal fieldnotes of shared-walking conversations in different settings, and 12 individual researchers theoretical and reflective memos expanding on personal experiences of entanglement that stuck in photographs, audio recordings, or simple memories of observations. This uneasy final sticky dataset is what we consider better talked to us about the mesh of children's heterotopic place-making and their creative and lived citizenship.

When we started the situational analysis (Clarke, 2005; Clarke, 2019) of the dataset, a part of it highlighted our abductions for being shared iconic stories about MAFA's place-making and children as citizens. Though they occurred in specific kindergartens, they were celebrated and treasured by the whole MAFA community. We considered them sticky data (MacRae et al., 2018) that not only existed in online pedagogical documentation (in MAFApp) or as photographs and text in our fieldnotes; they stood out as lively shared experience with participants, that returned in conversations as stories and tracings of MAFA's pedagogical enacted utopia.

Our situational analysis developed a rhizomatic coding exercise (Clarke, 2019) that involved slow work and long preparation (St. Pierre, 2018). First, to distinguish heterotopic place-making from other events and stories of children's spatialities, which condensed the dataset from 441 to 231 incidents of heterotopic place-making (210 excluded). Secondly, rhizomatic coding oriented us to make sense of children's heterotopias in terms of the three central ideas: The reality they disputed, the new inverting proposal, and the agencies involved. The more we engaged with the coding, literature revision, and participants' sense-making on the creative enactments of children's citizenship, the more isolated heterotopias became irrelevant. In doing so, the analysis turned to elicit types of intra-active relationalities involved in heterotopic place-making. 


\section{Findings: Types of Heterotopic Place-Making}

\section{Enacting Creative Citizenship}

The heterotopic place-making we find in kindergartens opens a new understanding of children's citizenship. We observe they assume a creative agentic role as 'already citizens' (Bath \& Karlsson, 2016), entangling in contesting place and meaning-making. This new perspective contrasts sharply with the upgraded national ECE curricular framework (Mineduc, 2018) and ECE teachers' utopias about learning environments. Children's unintended agentic activities were frequently considered daring behavior, unruly or challenging of teachers' pedagogies, and, consequently, unworthy of documentation as place-making and creative citizen enactment. A sample of 231 documentations uploaded to MAFApp (52\% of our corpus) shows children inhabiting the kindergarten in contestant ways and constitute insightful stories of heterotopic place-making. While 210 exhibited either the use of innovative spaces for children (e.g., reading corners, resting zones, selfcare, and building area) or children in participatory activities (e.g., choosing a play area, expressing opinions, collaborating with specific tasks or responsibilities) suggested in the national ECE framework. A teacher explained they wanted "to show how children are protagonists, but well behaved and playful within a controlled and organized environment" (Teacher Kindergarten 9, 2019). On this track, we observe heterotopic place-making encompasses different agendas and assumptions that are not always visible or declared (Millei \& Imre, 2016). From a Foucauldian perspective, this place-making performs educational utopias instead of enacting heterotopias as places of resistance within the normalized (Foucault, 1986).

We find three main categories of heterotopic place-making as lived citizenship or creative citizenship enactment: 1) unpredictable movements and wanderings, 2) new ruling artifacts, and 3) serendipitous spatial transgressions. New ruling artifacts heterotopias are the most documented in frequency, while serendipitous spatial transgressions are the least recurrent. This rate does not indicate the quantity of heterotopias two and three-yearold produce in kindergartens. Instead, it shows educators' bias regarding children's controversial place-making and the professional risk (Areljung \& Kelly-Ware, 2020) ECE teachers confront when choosing to share or discard heterotopias in pedagogical documentation.

\section{Unpredictable Movements: To Resist Docile Bodies and Inhabit their Own}

Before children even learn explicit spatial rules and understand the possibilities of the adult-staged spaces in the classroom, heterotopic place-making unfolds through their moving bodies (Hackett, 2014; Hackett 
\& Rautio, 2019). Hence, the first type of heterotopy we found children making to enact citizenship has their own body as the focus and territory to inhabit. The human body (child and adult) emerges as an unbounded organism in an entangled network of human and non-human forces (Murris, 2017a). Children built places with fortuitous bodily encounters and entangling their movements with materialities and given spaces. We found that two and three-year-old used their moves and wanderings as markers of spatial limits (Jobb, 2019) and as a way of emplacing new empowering realities. Children's heterotopic place-making emerged in casual joyful embodiments, unintended crossings, and unpredictable movements that actively resisted the teachers' instructions and overprotection of their assumed docile bodies (Foucault, 1984).

This heterotopic place-making manifests a self-sufficient body with a strong sense of where the body ends, and the world begins' (Manning, 2016). For example, in kindergarten 8 , Jo \& Je abruptly break and recreate a structured gross-motor exercising circle, delimited by the bodies of all children that had been instructed to stand over their stools, and repeat the teacher's movements (see figure 1). Both three-year-old boys conquer the useless and forgotten center of the human circle with deviant movements to, as they declared, "free rest." Their unexpected wandering of the circle center does not escape the established learning circumference but instead negotiates the circular space's understood spatial rules and limits. Within the teacher's arranged band (of docile bodies), Jo \& Je make a new place for their own ease. With their random actioning and combining their different postures, both boys make a heterotopic place, a new ring of resistance. This place-making shows awareness of the teaching area by dwelling within the circle but simultaneously contests its homogenizing definition and inverts its core of a noisy exercising border to a calm resting center.

In this heterotopic place-making, children's citizenship is an entanglement of human and non-human elements (Hohti, 2016) with no aprioristic purposes or intentionality (MacRae et al., 2018). Heterotopic place-making reveals spontaneously, in a moment, in the movement, and as bodies connect with the liveliness of things and invite pleasure of just moving and sensing (Hackett \& Rautio, 2019). It begins in the body and unfolds by exploring its possibilities for acting, being, and feeling. In this process, the kindergarten citizens inhabit their bodies as new worlds through the entanglement with materials, others, and spaces. For example, Ma \& Se (see figure 2) put away papers and stands of the art zone to use their own bodies as canvas. They start by squishing paint in the container, then expand to finger-scribbling on the table surface. Occasionally they look askance at the 
educator until they discover the pleasure of painting their own hands and arms with the brushes, and "be a painting!."

We argue this heterotopic place-making is 'thought-in-action' (Anderson \& Harrison, 2010) or 'thinking-in-movement' (MacRae et al., 2018). It outbreaks binarized citizenship visions attributed to giving children the power to choose or take it from the teachers, but always remaining in exclusive human agency. From this understanding, human bodily doings, wanderings, and movements entangle spaces and objects to erase limits between them and emplace citizenship while inhabiting the new reality. Ma $\&$ Se are conscious of where their body ends and begins the art zone (Manning, 2016). They enact citizenship interweaving with paintings, brushes, teachers' consent, surfaces, and joyful exploration to embody a place of artwork. We argue that through unpredictable movements and embodied places, children resist their objectification as docile bodies. Two and three-year-old inhabit the learning environment with no other purpose than dwelling the constant moving and sensing condition. Wanderings and movements empower children to live as creative citizens, similarly to hikers, skaters, and surfers, that entangle as citizen-flaneurs with a board to dwell waves and paved streets on the move (Allard, 2003).

Figure 1

Kindergarten 8

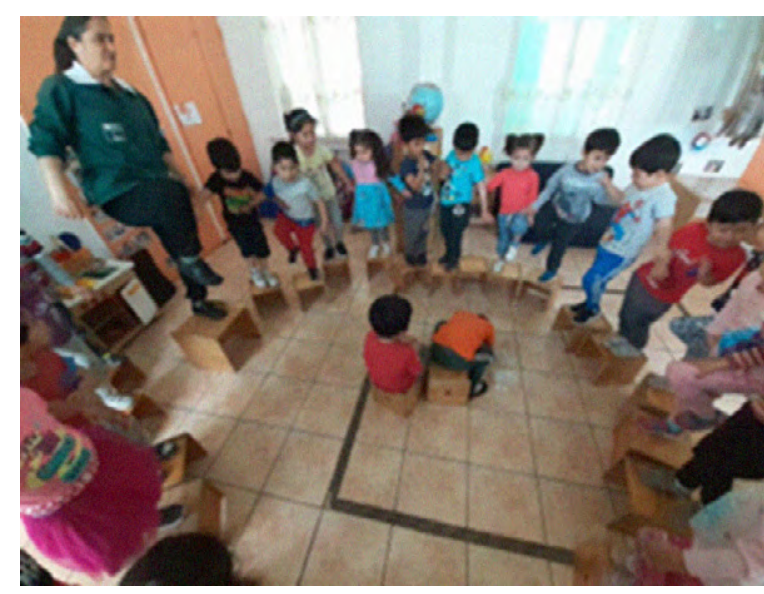

Source: Own source, based on documentation \#1298
Figure 2

Kindergarten 11

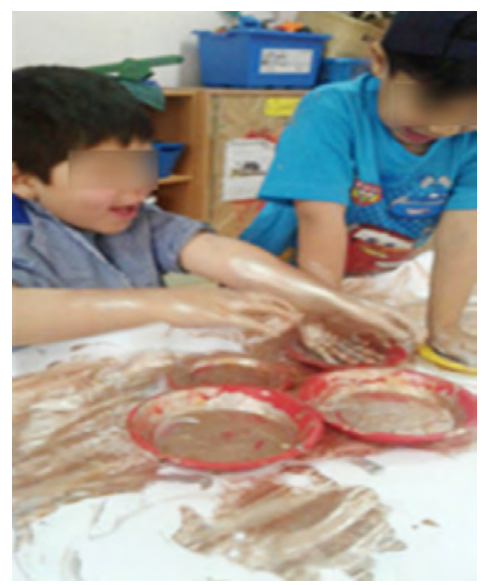

Source: Own source, based on documentation \#1476

New Ruling Artifacts: Resisting Adult Spaces to Inhabit Alternative Societies

Children enact their citizenship in the kindergarten making heterotopias through new ruling artifacts that resist and flip the imposed social order of life. In the words of Foucault, we observe these artifacts come 
into the classroom to "suspect, neutralize or invent the set of relations" (Foucault, 1984, p. 3) designated for childhood lives. As Hackett \& Rautio (2019), we found that two and three-year-old create things (MacRae et al., 2018) that activate new systems of value with the potential to interrupt predetermined social and cultural rules. Children's heterotopias manifest "alternative orderings" based on establishing new devices that bring with them new regulations and functionalities for the kindergarten. Hence, these heterotopias operate as developing mediations for children to push the boundaries of the realities they inhabit and overthrow the naturalized hegemonic cultures and social regularities they live by.

In Kindergarten 4, during a period of free play, a group of eight girls and boys started collecting things from the first aid kit and the classroom stools (from different corners) to build a bus in the center of the classroom that would "take them to the hospital" (see figure 3). As they emergently engaged in the idea of traveling together for healthcare and sited in the bus, simultaneous dialogues (verbal and non-verbal) explained the incorporation of other elements to build the vehicle and their outfits, per the occasion. As Ag puts on a flowery hat, a leather purse and takes his Captain America in need of medical assistance, he sits in the front seat, calling himself "the driver." Ma approaches the driver and requests admission by saying "Mam, I am going to the hospital," to which Ag friendly answers "Come in, I am not a mam, I am a mister with a purse." This exemplar event of heterotopic place-making beats pure representational dramatic play and unveils an alternative society where adult conventions are inverted. Children created a place of resistance where strong and self-sufficient adult men get sick (such as Captain America) and wear feminine attire remaining masculine. We argue this healthy-bus heterotopia emerges with gender roles that rewrite the quotidian signs of naturalized heteronormativity in children's everyday life.

We found that children enact citizenship in kindergarten when they build artifacts that bring-in new rules to disrupt teachers' pedagogical normativity. Two and three-year-old turn ECE teachers' pedagogies and objects into their territory to reshuffle the indisputable ties between teaching-learning and specific spaces. For example, Pi, El, and Am conquer an abandoned mirror on the back of an art shelf (intended for self-portrait artwork) to use it with crayons as a vanity table for unauthorized makeup (see figure 4). The girls' dialogue emplaced in the unprecedented vanity table builds a new rule about pampering themselves with "available art material" to "makeup lips and blush cheeks," overthrowing the instruction that "only adults makeup in the kindergarten." 
Figure 3

Kindergarten 4

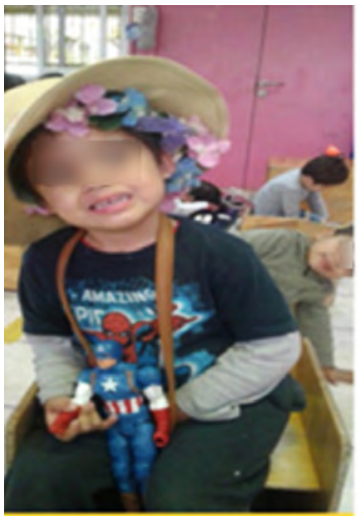

Source: Own source, based on documentation \#1173
Figure 4

Kindergarten 2
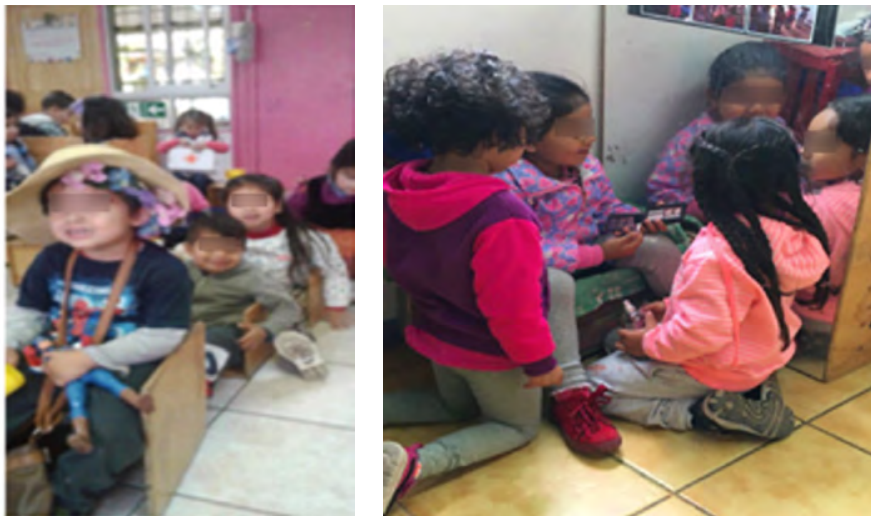

Source: Own source, based on documentation \#1344

The new artifact in the classroom empowers them to resist ageist stereotypes of self-personal care. So, when the teacher discovers this event and offers her own eyeshadows inquiring about their aesthetic makeup criteria and experience, they all engage in an intergenerational negotiation of place-making to inhabit an adult world of fashion and daring beauty otherwise is impenetrable. From a Foucauldian perspective, the girls' heterotopic place-making enacts citizenship by building a world of hidden appearance, or a tentative territory for a particular society to gather forces and one-day break-ground in the public space (Foucault, 1984). Moreover, these new ruling artifacts not only disrupt dominant culture and power relations but profoundly democratize learning environments. We observe what Barden (2016) calls "heterotopic affinity spaces," which are emplaced entanglements with deep and authentic learning around a shared endeavor (Barden, 2016). In this type of heterotopic place-making, all the human and non-human involved gain collective power and are equal dwellers: "Nothing is considered to stand outside or above or to take a true, privileged, transcendental position" (Murris, 2017a, p. 22).

\section{Serendipitous Spatial Transgressions: Displacing Pedagogies and Resisting Prescribed Curricular Citizenship from Within}

Heterotopias that seem most empowering of children's citizenship are serendipitous spatial transgressions. Through this heterotopic place-making, children challenge teacher-solely defined geographies in the kindergarten. Children recognize fortuitous conditions to transgress learning areas planned for them and build their own spatialization, rather than remaining utterly confined within staged limits (Pitsikali \& Parnell, 2019) 
and teaching-learning places. With these everyday heterotopias, two and three-year-old displace binarized pedagogies (adult or child-centered) and reconfigure, along with their teachers, the prescribed curricular citizenship. Hence, the unfolding of spatial transgressions engages children and adults in the public realm and makes a stance to resist it from within.

The spatial transgressions are not an infraction to limits, nor should they be understood as disobedience to the classroom teachers' rules. We argue an entanglement where children as citizens show creative use of abandoned and useless adult spaces to speak out their own story or position about learning and living in the kindergarten. We observe serendipitous spatial transgressions as heterotopias that displace pedagogies out of sophisticated staged learning centers and highly implemented teaching areas (e.g., home corner, classroom library, science, and sensory exploration sections). Two and three-year-old resist, with their ever-evolving spatial transgressions, their teachers' pedagogical utopias that suggest social ideals of play and autonomous learning (Taylor \& Richardson, 2005). Children displace, invert or dismantle fixed spaces and staged corners meant for teaching and learning within the lived curriculum. Following Foucault's metaphor of lighting in the night, these heterotopias alert and destabilize the curricular status quo by "lighting up from the inside, and yet owing to the dark the stark clarity of its manifestation" (Foucault, 1986, p. 74).

Sam \& Agu have five different learning centers in their classroom to choose daily for free play. These spaces approach with a plethora of resources the learning cores and playful environment guidelines of the curricular framework: A classroom library, a building area, an atelier-art space, a scientific experimentation corner, and an ample and thoroughly implemented home corner. However, Sam \& Agu displace the intended pedagogies of these staged spaces in the classroom into the teacher's private office-space of individual administrative work (see figure 5). Within the forgotten desk leg, girls create a new place: An ice-cream shop heterotopia were shouting "ice-cream, ice-cream!", "Who wants ice-cream?" to sell is allowed, and where they learn about "yummy chocolate flavor" and "counting money to pay." We postulate that the ECE teacher authorizing this spatial transgression heterotopia, from a distance with a smile and observable documentation, is an acknowledgment for the girls of the conquest they have achieved. This subtle negotiation between children and ECE teachers shows serendipitous spatial transgressions that enact children's citizenship in the kindergarten.

At first glance, as MacRae et al. (2018) observe in museums, this situation may be considered disruptive behavior and finds no constructive explanation in dominant models of ECE learning spaces and citizenship. In effect, 
we find serendipitous spatial transgressions are of children's productions in the kindergarten, the least documented by teachers. Precisely because educators and other adults tend to see these low-income and color children's actions as rebellious play and misbehaving (Hackett \& Rautio, 2019), records do not frequently value them as relevant place-making, intended expressions of children's citizenship, or evidence of citizenship learning outcomes of the learning framework. However, in our fieldnotes and interviews, we find that these heterotopias frequently arise in all participating Kindergartens and enact citizenship by turning sacralized spaces of order and pedagogical appropriateness (Hackett \& Rautio, 2019) into a shared territory that reshuffles indisputable emplacements of teaching-learning in the kindergarten.

These heterotopias enact citizenship because they have the potential to interrupt the predetermined order of things and empower children with their own stories of alternative worlds. In serendipitous spatial transgressions, children unfold their unique ways of knowing and engage with others as "more-than-human multimodal meaning makers" (Hackett \& Rautio, 2019, p. 1024). Children dare pedagogical objects, intended affordances, and assumed functionalities (Pitsikali \& Parnell, 2019), engaging in the process of growth and ongoingness where shared meanings of place emerge. For example, in Kindergarten 11, Ne \& Le ally "to rest and regain strength in the yoga gear's ledges" (see figure 6). While trying out their ideas, they reorganize the material shelves and find reasons such as "darkness" and "quiet" to "climb in with no shoes," and "sleep well." Ne \& Le build their story as they entangle in the "cabin bunk bed" making and share compliance on disregarding the existing rest areas, comfortable mats, and nap beds.

Figure 5

Kindergarten 13

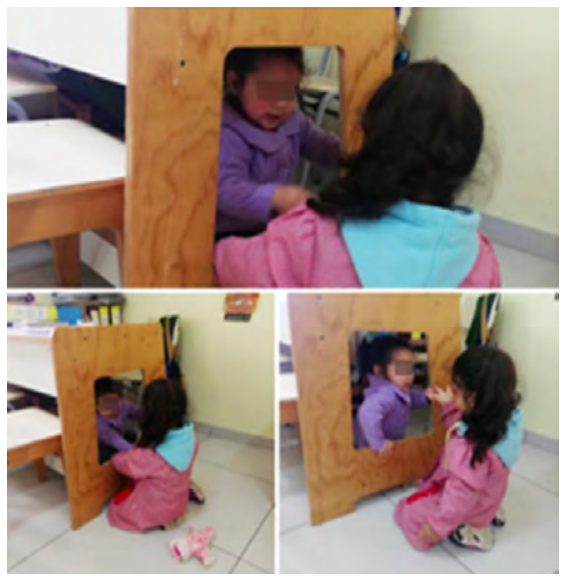

Source: Own source, based on documentation \#1215
Figure 6

Kindergarten 11

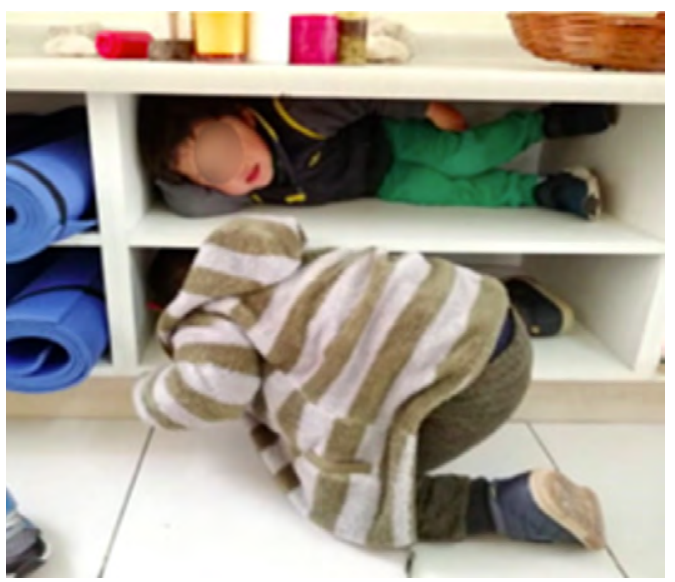

Source: Own source, based on documentation \#1227 
Likewise, in Kindergarten 6, Ro \& Da take racing cars from the construction area to a new window lintel over the heating radiator. Only teachers use this place for storage and encourage children to keep safe from burning. However, it is there that Ro \& Da build a "risky highway," where they have enough knowledge to "avoid crashing despite the sun" and are skillful enough to "arrive safely home" and "on-time" (see figure 7). As Hackett \& Rautio (2019), we observe this heterotopic place-making is not anticipated or planned by children but rather serendipitous. Spatial transgressions unfold along with the making of the place through the entanglement (Hackett, 2015) of objects, movements, and intense emotions of those involved (Hackett \& Rautio, 2019; Thiel, 2015).

Serendipitous spatial transgressions engage children in forcing pedagogies out of their curricular intended emplacement. They move teachers' utopias of personal rest, dramatic play, and collaborative learning from correctly implemented spaces for resting, playing, and learning to alternative places. Children manage to engage in different ways of inverting predetermined learning sites of the curriculum into new emplaced stories about knowledge building and belonging to a community. As Pitsikali \& Parnell (2019) observe in playgrounds, we find that carefully staged layouts in the kindergarten, for fair participation and proper behaviors, collapse before children's stories of heterotopic place-making. In Kindergarten 2, a teacher displayed in the center of the classroom a wooden cube with yarn webs on the sides and a knitted shawl as a roof (see figure 8). She planned to provoke "a place for children's playful exploration of partial darkness." However, An \& Ma, in few minutes, team-up to pull down the roof and turn the enclosed teaching space into an opened hammock. Along with rocking, An invites Ma "here with me" to share the experience. Ma accepts with an excited "yeah, yesss!" that accompanies his climbing-on and extends unfolding storytelling through their rocking and babbling coordinations on the hammock.

Figure 7

Kindergarten 6

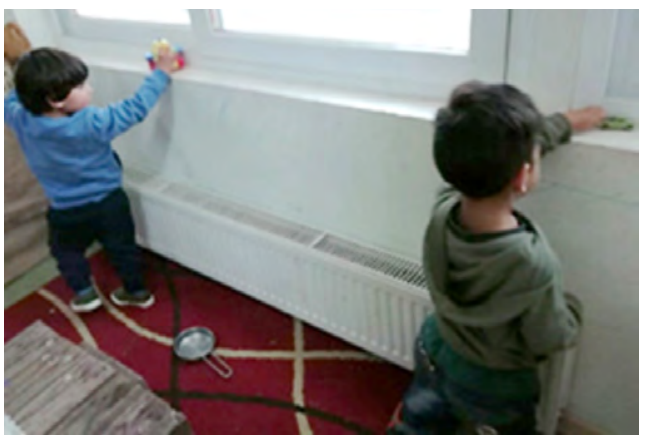

Source: Own source, based on documentation \#1316
Figure 8

Kindergarten 2

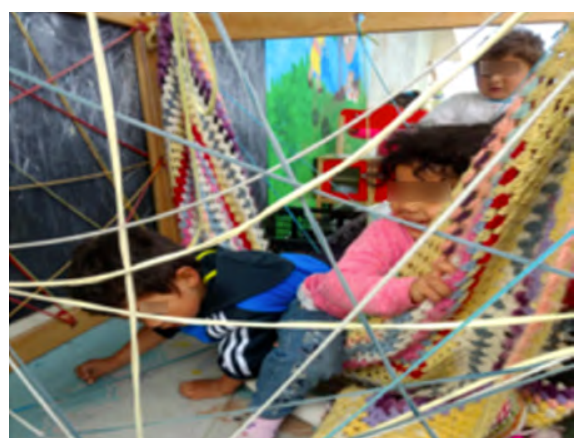

Source: Own source, based on

documentation \#1322 
We observe this heterotopic place-making involves "intense surges of emotion to which children's moving bodies respond" (Hackett \& Rautio, 2019 , p. 1023) while entangling with things and teachers' approval in the heterotopic place-making experience. Serendipitous spatial transgressions enact creative citizenship while mediating new orderings. They simultaneously alter the given spaces, emplace an alternative reality within the prevailing constraints, alternating and flowing between realities.

\section{Discussion and Conclusions}

This article argues heterotopic place-making comprises creative citizenship (Hargreaves \& Hartley, 2016a; Marsh et al., 2018) because it builds new places of alternate ordering that entangle diverse forms of collaboration and social expression in the kindergarten (Hargreaves \& Hartley, 2016a, p. 11). From a Foucauldian heterotopology (Foucault, 1986) and a posthumanist premise of childhood (Murris, 2016), our results reconceptualize children's unpredictable movements and wanderings, new ruling artifacts, and serendipitous spatial transgressions, as creative heterotopic entanglements that enact citizenship.

We posit this understanding opens up new possibilities of boosting citizen lives in the kindergarten, even when it happens unexpectedly, with little words, almost no adult interactions, and no teachers' intentionality (Hargreaves \& Hartley, 2016a). Children's creative citizenship rises with heterotopias' serendipity and unfolds because heterotopic place-making is shared thinking-in-action (MacRae, 2011; MacRae et al., 2018) and appears intuitively understandable by all (equal) dwellers (Hargreaves \& Hartley, 2016b; Millei \& Imre, 2016). We find that children's creative citizenship will blossom wherever pedagogies and spatialities are less constraining and pedagogically embrace posthuman entanglements to make "whatever you want it to be places" (Fors et al., 2013, p. 15). Also, within ECE learning environments that dare to move beyond colonizing onto-epistemologies, heterotopic place-making gathers the power of children's voluntary association to influence togetherness and the common good (Pink, 2012).

Creative citizenship through heterotopic place-making is not a teachers' loan of space or pass to skilfulness. We find two and three-year-old do not wait passively for adults to lend such empowerment or open spaces to participate. Instead, they live enacting citizenship through everyday heterotopic practices that empower them to simultaneously alter, contest, and invert the social regularities they live by. This new understanding foregrounds children living as citizens when they resist dwelling teachers' pedagogical utopias and engage in agentic experiences that make alternative realities 
possible. Albeit these practices may be ignored as citizenship or considered naughty behaviour by adults, children as heterotopians live creative citizenship that empowers them as inhabitants of social life and equal dwellers.

We are aware of how this new understanding challenges public curricular and architectural ECE policies to go beyond children's conventional protagonism in fixed spaces of play, rituals of civic engagement, and participation by assignment of classroom duties. In this regard, our study's claimable limitation is precisely having contained the ethnographic field to the Chilean MAFA case, renowned for its publicly supported innovative physical learning environments and its online ECE teachers' place-based community. Further research in mainstream public kindergartens is required to deepen the understanding of creative citizenship conditions of possibility in mainstream learning environments. As Gosling (2014) commented about Centres for Excellence in Teaching and Learning (CETLs) in the UK, they were funded by the Education Council of England to "become enacted pedagogical utopias" (Gosling, 2014, p. 25). However, disconnected from mainstream educational policy, they disappeared when funding ended. How possible are children's creative enactments of citizenship we observed in constraining kindergartens and more schoolified learning environments (Pardo \& Opazo, 2019), is a question we could not reach in our inquiry.

Our main contention is to reconceptualize ECE learning environments for citizenship as shared place-making between human and non-human actants that flows (Csikszentmihalyi, 1990) in creating alternative worlds. We introduce this notion to highlight that everyday-heterotopic citizenship is lived as a positive human experience of joy, engagement, and creativity. It does not imply taking away ECE teachers' control and pedagogies. Instead, it invites a fluid view (Duckles et al., 2019) of learning environments and teachers' improvisatory practices (MacRae et al., 2018), valuing children's unexpected place negotiations that unfold new alternative spatialities. Acknowledging that children live citizenship as heterotopians in their learning environments, and therefore are already-citizens empowered with democratic values (Sounoglou \& Michalopoulou, 2016), inevitably calls for pedagogies to entangle less as consumers of given learning environments and more as heterotopic place-makers.

\section{Acknowledgements}

Special gratitude to the FONDEF Program of ANID for financing the FONDEF IT1410120 project. Also, to the parties of the MAFA to JUNJI Licensing Agreement (2018-2022) for their support with resources for the technological transfer of MAFA to the national territory. 


\section{About the authors}

Cynthia Yael Adlerstein-Grimberg is currently an academic at the Faculty of Education and a research associate of CEPPE at the Pontifical Catholic University of Chile, from where she directs MAFA's R\&D line. She is also a consultant of the World Bank on early childhood education and is a CNA Counselor on the Graduate Committee.

Andrea Bralic-Echeverría is a Kindergarten educator from the Pontifical Catholic University of Chile, with a Major in Early Education and certificated in Educational Resources and Play. Since 2015 she has been part of the MAFA research team, supporting data collection, analysis of data and the technical-pedagogical management. In 2018 and 2019 she is a Kindergarten Educator in a Kindergarten.

\section{References}

Adlerstein, C. (2017). Rediseñar la distribución del poder en las aulas públicas. In M. Mendoza \& R. Ferrer (Eds.), Nuevos ambientes de aprendizaje en educación parvularia (p. 259). https://www.junji.gob.cl/wp-content/up loads/2017/08/Libro-OMEP.pdf

Adlerstein, C., Manns, P. \& González, A. (2018). Pedagogías para habitar el jardín infantil. Construcciones desde el modelamiento del ambiente físico de aprendizaje. UC.

Allard, P. (2003). Las dimensiones del juego: la ciudad como campo y escenario. ARQ (Santiago), (55), 5-8. https://doi.org/10.4067/s0717-6996200 3005500002

Anderson, B. \& P. Harrison. (2010). The promise of non-representational theories. In Taking-place: Nonrepresentational theories and geography (pp. 1-36). Ashgate.

Andrade, P. (2017). Construcción del espacio educativo desde el territorio. In M. Mendoza \& R. Ferrer (Eds.), Nuevos ambientes de aprendizaje en educación parvularia (p. 260). Ediciones de la Junji. https://www.junji.gob.cl/wp-con tent/uploads/2017/08/Libro-OMEP.pdf

Archard, S. \& Archard, S. (2019). Establishing a learner identity: Young digital citizens and the pursuit of a democratic and empowering early childhood education. In International perspectives on early childhood education and development (pp. 153-165). Springer. https://doi.org/10.1007/978-981-137771-6_11

Areljung, S. \& Kelly-Ware, J. P. (2020). The risks of reification: Using 'professional risk' to understand why and how teachers choose to document (some of) children's ideas and actions. In M. Alasuutari, H. Kelle \& H. Knauf (Eds.), Documentation in institutional contexts of early childhood: Normalisation, participation and professionalism (pp. 187-204). Springer. https://doi. org/10.1007/978-3-658-28193-9_10

Atkinson, D. (2002). Art in education: Identity and practice. Kluwer Academic. 
Atkinson, D. (2012). Contemporary art and art in education: The new, emancipation and truth. International Journal of Art and Design Education, 31(1), 5-18. https://doi.org/10.1111/j.1476-8070.2012.01724.x

Baker, F. S. (2013). Responding to the challenges of active citizenship through the revised UK early years foundation stage curriculum. Early Child Development and Care, 183(8), 1115-1132. https://doi.org/10.1080/03004430. 2013.792254

Barden, O. (2016). Heterotopic affinity spaces. Power and Education, 8(3). https:// doi.org/10.1177/1757743816677134

Bath, C. \& Karlsson, R. (2016). The ignored citizen: Young children's subjectivities in Swedish and English early childhood education settings. Childhood, 23(4). https://doi.org/10.1177/0907568216631025

Biroli, P., Del Boca, D., Heckman, J., Pettler, L., Kyung, Y., Kuperman, S., Moktan, S., Pronzato, C. \& Ziff, A. (2017). Evaluation of the Reggio approach to early education evaluation of the Reggio approach to early education. Institute of Labor Economics.

Blackmore, J., Bateman, D., O'Mara, J. \& Loughlin, J. (2011). The connections between learning spaces and learning outcomes: People and learning places? http://www.learningspaces.edu.au/docs/learningspaces-literature-review.pdf

Bryant, A., Charmaz, K., Duckles, J. M., Moses, G. \& Moses, R. (2019). Community-based participatory research and constructivist grounded theory: Aligning transformative research with local ways of being and knowing. In A. Bryant \& K. Charmaz (Eds.), The Sage handbook of current developments in grounded theory. Sage. https://doi.org/10.4135/9781526485656.n33

Burney, D. \& Claflin, A. (2016). Practical considerations for implementing research on the indoor built environment. Building Research and Information, 44(3), 342-344. https://doi.org/10.1080/09613218.2015.1088225

Cardellino, P., Araneda, C. \& García Alvarado, R. (2017). Classroom environments: An experiential analysis of the pupil-teacher visual interaction in Uruguay. Learning Environments Research, 20(3), 417-431. https://doi.org/10.1007/ s10984-017-9236-y

Cavallini, I., Quinti, B., Rabotti, A. \& Tedeschi, M. (2017). Las arquitecturas de la educación: el espacio de lo posible. La cultura del habitar en la experiencia de las escuelas municipales de educación infantil de Reggio Emilia. Revista Internacional de Educación para la Justicia Social (RIEJS), 6(1), 181-197. https://doi.org/10.15366/riejs2017.6.1.010

Charteris, J., Jones, M., Nye, A. \& Reyes, V. (2017). A heterotopology of the academy: Mapping assemblages as possibilised heterotopias. International Journal of Qualitative Studies in Education, 30(4), 340-353. https://doi.org /10.1080/09518398.2016.1250178

Clark, M. (2019). Edges and boundaries: Finding community and innovation as an early childhood educator. Early Childhood Education Journal, 47(2), 153-162. https://doi.org/10.1007/s10643-018-0904-z

Clarke, A. (2019). Situating grounded theory and situational analysis. In A. Bryant \& K. Charmaz (Eds.), The Sage handbook of current developments in grounded theory (pp. 3-48). Sage. https://dx.doi.org/10.4135/9781526 485656.n3 
Clarke, A. E. (2005). Situational analysis: Grounded theory mapping after the postmodern turn. Sage.

Cortés, C., Adlerstein, C. \& Bravo, Ú. (2020). Early childhood teachers making multiliterate learning environments: The emergence of a spatial design thinking process. Thinking Skills and Creativity, 36(November 2019), 100655. https://doi.org/10.1016/j.tsc.2020.100655

Csikszentmihalyi, M. (1990). Flow the psychology of optimal experience. HarperCollins.

Dahlberg, G., Moss, P. \& Pence, A. (2007). Beyond quality in early childhood education and care: Languages of evaluation (Second Edition). Roudtlege. https://doi.org/10.4324/9780203966150

Dahlberg, G., Moss, P. \& Pence, A. (2013). Beyond quality in early childhood education and care: Languages of evaluation (3rd edition). Routledge. https:// doi.org/10.4324/9780203371114

De Cauter, L. \& Dehaene, M. (2008). The space of play: Towards a general theory of heterotopia. In L. De Cauter \& M. Dehaene (Eds.), Heterotopia and the city: Public space in a postcivil society (pp. 87-102). Routledge. https://doi. org/10.4324/9780203089415

De Coninck-Smith, N. \& Gutman, M. (2004). Children and youth in public: Making places, learning lessons, claiming territories. Childhood, 11(2). https:// doi.org/10.1177/0907568204043048

Devine, D. \& Cockburn, T. (2018). Theorizing children's social citizenship: New welfare states and inter-generational justice. Childhood, 25(2). https://doi. org/10.1177/0907568218759787

Dovey, K. \& Fisher, K. (2014). Designing for adaptation: The school as socio-spatial assemblage. Journal of Architecture, 19(1), 43-63. https://doi.org/10.1 080/13602365.2014.882376

Duarte, J., Jaureguiberry, F. \& Racimo, M. (2017). Suficiencia, equidad y efectividad de la infraestructura escolar en América Latina según el TERCE. https://publications.iadb.org/bitstream/handle/11319/8158/Suficiencia-equi dad-y-efectividad-de-la-infraestructura-escolar-en-America-Latina-segunel-TERCE.PDF?sequence $=3$

Duhn, I. (2012). Making 'place' for ecological sustainability in early childhood education. Environmental Education Research, 18(1), 19-29. https://doi.or g/10.1080/13504622.2011.572162

Earl-Rinehart, K. (2020). Abductive analysis in qualitative inquiry. Qualitative Inquiry, 27(2). https://doi.org/10.1177/1077800420935912

Edwards, C. P., Gandini, L. \& Forman, G. E. (1998). The hundred languages of children: The Reggio Emilia approach; advanced reflections. In C. P. Edwards, L. Gandini \& G. E. Forman (Eds.), Hundred languages of children (pp. 457-466). Ablex.

Esser, F. (2016). Neither 'thick' nor 'thin': Reconceptualising agency and childhood relationally. In F. Esser, M. S. Baader, T. Betz \& B. Hungerland (Eds.), Reconceptualising agency and childhood: New perspectives in childhood studies (pp. 48-61). Routledge. https://doi.org/10.4324/9781315722245 
Falabella, A. (2014). The performing school: The effects of market \& accountability policies. Education Policy Analysis Archives, 22-70. https://doi. org/10.14507/epaa.v22n70.2014

Ferrare, J. J. \& Apple, M. W. (2010). Spatializing critical education: Progress and cautions. Critical Studies in Education, 51(2), 209-221. https://doi. org/10.1080/17508481003731075

File, N. (2012). Identifying and addressing challenges to research in university laboratory preschools. Early Education and Development, 23(2), 143-152. https://doi.org/10.1080/10409289.2012.619136

Fors, V., Bäckström, ̊. \& Pink, S. (2013). Multisensory emplaced learning: Resituating situated learning in a moving world. Mind, Culture, and Activity, 20(2), 170-183. https://doi.org/10.1080/10749039.2012.719991

Foucault, M. (1984). Of other spaces, heterotopias. Architecture, Mouvement, Continuite. https://web.mit.edu/allanmc/www/foucault1.pdf

Foucault, M. (1986). Of other spaces. Diacritics, 16(1), 22-27.

Foucault, M. (1994). The order of things: An archeology of the human sciences. Tavistock.

Foucault, M. (1998). Different spacess. In J. Faubion (Ed.), Aesthetics: The essential works 2 (pp. 175-85). Allen Lane.

Foucault, M. \& Faubion, J. D. (1998). Aesthetics, method, and epistemology. Essential works of Foucault, 1954-1984. https://doi.org/10.1002/car.1158

Franz, R. J. (2019). Preschool in the park: Place-based learning in unexpected spaces what is place-based education? USA.

Gandini, L. (2011). Play and the hundred languages of children: An interview with Lella Gandini. Americal Journal of Play, 4(1), 1-18.

Gosling, D. (2014). Teaching and learning projects as 'heterotopias'. Critical Studies in Teaching and Learning, 2(1), 25-48. https://doi.org/10.14426/cristal. v2i1.18

Gruenewald, D. A. (2003). The best of both worlds: A critical pedagogy of place. Educational Researcher, 32(4), 3-12. https://doi.org/10.3102/0013 189X032004003

Gruenewald, D. A. (2008). Place-based education: Grounding culturally responsive teaching in geographical diversity. In G. A. Smith \& D. A. Gruenewald (Eds.), Place-based education in the global age: Local diversity (pp. 137154). Routledge Taylor \& Francis.

Hackett, A. (2015). Children's embodied entanglement and production of space in a museum. In A. Hackett, L. Procter \& J. Seymour, (Eds.), Children's spatialities (pp. 75-92). Palgrave Macmillan. https://doi.org/10.1057/9781 1374649895

Hackett, A., Pahl, K. \& Pool, S. (2017). In amongst the glitter and the squashed blueberries: Crafting a collaborative lens for children's literacy pedagogy in a community setting. Pedagogies, 12(1), 58-73. https://doi.org/10.1080/1 554480X.2017.1283994

Hackett, A., Procter, L. \& Seymour, J. (2015). Introduction: Spatial perspectives and childhood studies. In Children's spatialities (pp. 1-17). Palgrave. https:// doi.org/10.1057/9781137464989_1 
Hackett, A. \& Rautio, P. (2019). Answering the world: Young children's running and rolling as more-than-human multimodal meaning making. International Journal of Qualitative Studies in Education, 32(8), 1019-1031. https://doi.or $\mathrm{g} / 10.1080 / 09518398.2019 .1635282$

Hackett, A. \& Somerville, M. (2017). Posthuman literacies: Young children moving in time, place and more-than-human worlds. Journal of Early Childhood Literacy, 17(3), 374-391. https://doi.org/10.1177/1468798417704031

Hargreaves, I. \& Hartley, J. (2016a). A capacious approach to creative citizenship: Implications for policy. In I. Hargreaves \& J. Hartley (Eds.), The creative citizen unbound: How social media and DIY culture contribute to democracy, communities and the creative economy. Policy. https://doi.org/10.1332/ policypress/9781447324942.003.0011

Hohti, R. (2016). Now-and now-and now: Time, space and the material entanglements of the classroom. Children and Society, 30(3), 180-191. https:// doi.org/10.1111/chso.12135

Hong, S. B., Shaffer, L. S. \& Han, J. (2017). Reggio Emilia inspired learning groups: Relationships, communication, cognition, and play. Early Childhood Education Journal, 45(5), 629-639. https://doi.org/10.1007/s10643-016-0811-0

Hoyuelos, A. (2005). La cualidad del espacio-ambiente en la obra pedagógica de Loris Malaguzzi. In I. Cabañelas \& C. Eslava (Coords.), Territorios de la infancia: diálogos entre arquitectura y pedagogía (pp. 49-58). GRAO.

James, A. (2011). To be (come) or not to be (come): Understanding children's citizenship. Annals of the American Academy of Political and Social Science, 633(1). https://doi.org/10.1177/0002716210383642

Jobb, C. (2019). Power, space, and place in early childhood education. Canadian Journal of Sociology, 44(3). https://doi.org/10.29173/cjs29596

Kernan, M. (2010). Space and place as a source of belonging and participation in urban environments: Considering the role of early childhood education and care settings. European Early Childhood Education Research Journal, 18(2), 199-213. https://doi.org/10.1080/13502931003784420

Könings, K. D., Bovill, C. \& Woolner, P. (2017). Towards an interdisciplinary model of practice for participatory building design in education. European Journal of Education, 52(3), 306-317. https://doi.org/10.1111/ejed.12230

Larkins, C. (2014). Enacting children's citizenship: Developing understandings of how children enact themselves as citizens through actions and Acts of citizenship. Childhood, 21(1). https://doi.org/10.1177/0907568213481815

Larkins, C. (2016). Making the critical links: Strategies for connecting marginalised children's action research with European citizenship. Revista de Asistenta Sociala (Social Work Review), 15(2), 11-23. https://proxy.lib.ohiostate.edu/login?url=http://search.ebscohost.com/login.aspx?direct=true\&d $b=$ swh\&AN $=89248 \&$ site $=$ ehost-live

Lassiter, L. E. \& Campbell, E. (2010). What will we have ethnography do? Qualitative Inquiry, 16(9). https://doi.org/10.1177/1077800410374444

Lather, P. \& St. Pierre, E. A. (2013). Post-qualitative research. International Journal of Qualitative Studies in Education, 26(6), 629-633. https://doi.org/10.108 0/09518398.2013.788752 
Lindgren, T. (2020). The figuration of the posthuman child. Discourse, 41(6), 914-925. https://doi.org/10.1080/01596306.2019.1576589

Lister, R. (2007). Inclusive citizenship: Realizing the potential. Citizenship Studies, 11(1), 49-61. https://doi.org/10.1080/13621020601099856

Mac Naughton, G. (2005). Doing Foucault in early childhood studies. In Doing Foucault in early childhood studies (pp. 5-23). Routledge. https://doi. org/10.4324/9780203465332

MacRae, C. (2011). Making Payton's Rocket: Heterotopia and lines of flight. International Journal of Art and Design Education, 30(1), 102-112. https://doi. org/10.1111/j.1476-8070.2011.01686.x

MacRae, C., Hackett, A., Holmes, R. \& Jones, L. (2018). Vibrancy, repetition and movement: Posthuman theories for reconceptualising young children in museums. Children's Geographies, 16(5), 503-515. https://doi.org/10.108 0/14733285.2017.1409884

Mahat, M., Bradbeer, C., Byers, T. \& Imms, W. (2018). Innovative learning environments and teacher change: Defining key concepts. https://doi.org/ 10.13140/RG.2.2.12508.28802

Manning, E. (2016). The minor gesture. In The minor gesture (pp. 1-25). Duke University Press. https://doi.org/10.1215/9780822374411

Marsh, J., Arnseth, H. C. \& Kumpulainen, K. (2018). Maker literacies and maker citizenship in the makey (Makerspaces in the early years) project. Multimodal Technologies and Interaction, 2(3), 50. https://doi.org/10.3390/ mti2030050

Marshall, T. H. (1950). Citizenship and social class. Cambridge University Press.

McNamee, S. (2000). Foucault's heterotopia and children's everyday lives. Childhood, 7(4), 479-492. https://doi.org/10.1177/0907568200007004006

Melhuish, E., Howard, S. J., Siraj, I., Neilsen-Hewett, C., Kingston, D., De Rosnay, M., Duursma, E. \& Luu, B. (2016). Fostering Effective Early Learning (FEEL) through a professional development programme for early childhood educators to improve professional practice and child outcomes in the year before formal schooling: Study protocol for a cluster randomised controlled trial. Trials, 17(602). https://doi.org/10.1186/s13063-016-1742-1

Millei, Z. \& Imre, R. (2009). The problems with using the concept of 'citizenship' in early years policy. Contemporary Issues in Early Childhood, 10(3). https:// doi.org/10.2304/ciec.2009.10.3.280

Millei, Z. \& Imre, R. (2015). "Down the toilet": Spatial politics and young children's participation. In K. Kallio, S. Mills \& T. Skelton (Eds.), Politics, citizenship and rights (pp. 1-14). Springer. https://doi.org/10.1007/978-981-4585-94-1_27-2

Millei, Z. \& Imre, R. (2016). Introduction: Childhood and nation. In Childhood and nation (pp. 1-22). Palgrave Macmillan. https://doi.org/10.1057/ 9781137477835_1

Miller, V. (2019). Creating the third teacher through participatory learning environment design: Reggio Emilia principles support student wellbeing. In J. Willis, J. Franz \& H. Hughes (Eds.), School spaces for student wellbeing and learning: Insights from research and practice (pp. 239-258). Springer. https://doi.org/10.1007/978-981-13-6092-3_13 
Mills, K. A. \& Comber, B. (2013). Space, place, and power: The spatial turn in literacy research. In K. Hall, T. Cremin, B. Comber \& L. C. Moll (Eds.), International handbook of research on children's literacy, learning, and culture (pp. 412-423). John Wiley. https://doi.org/10.1002/9781118323342.ch30

Mineduc. (2018). Bases curriculares en educacion parvularia. Subsecretaría de Educación Parvularia.

Mineduc. (2019). Ambientes de aprendizaje. Orientaciones técnico-pedagógicas para el nivel de educación parvularia. https://parvularia.mineduc.cl/wp-content/uploads/sites/34/2019/08/AMBIENTES-final.pdf

Moss, P. (2017). Power and resistance in early childhood education: From dominant discourse to democratic experimentalism. Journal of Pedagogy, 8(1), 11-32. https://doi.org/10.1515/jped-2017-0001

Moss, P. (2018a). Alternative narratives in early childhood: An introduction for students and practitioners. In Alternative narratives in early childhood: An introduction for students and practitioners (pp. 1-26). Routledge. https:// doi.org/10.4324/9781315265247

Moss, P. (2018b). Posthumanism, the posthuman child and intra-active pedagogy. In Alternative narratives in early childhood: An introduction for students and practitioners (pp. 141-169). Routledge. https://doi.org/10.4324/ 9781315265247-7

Moss, P., Dahlberg, G., Grieshaber, S., Mantovani, S., May, H., Pence, A., Rayna, S., Blue, B. \& Vandenbroeck, M. (2016). The organisation for economic co-operation and development's international early learning study: Opening for debate and contestation. Contemporary Issues in Early Childhood, 17(3). https://doi.org/10.1177/1463949116661126

Moss, P. \& Moss, P. (2018). Reggio Emilia: A story of democracy, experimentation and potentiality. In Alternative narratives in early childhood. Routdlege.

Murris, K. (2016). The posthuman child. Educational transformation through philosophy with picturebooks (1st ed.). Routledge.

Murris, K. (2017a). Reading two rhizomatic pedagogies diffractively through one another: A Reggio inspired philosophy with children for the postdevelopmental child. Pedagogy, Culture and Society, 25(4), 531-550. https://doi.or g/10.1080/14681366.2017.1286681

Murris, K. (2017b). The posthuman child: III. In D. Kennedy \& B. Bahler (Eds.), Philosophy of childhood today. Exploring the boundaries (pp. 185-198). Lexington Books.

Myers, C. Y. (2015). Children, among other things: Entangled cartographies of the more-than-human kindergarten classroom [Doctoral dissertation, Kent State University]. Proquest. https://search. proquest.com/openview/ $161 f 51 a 3 c 68 f 274 a d 57 f 6161 c 7197 e 2 e / 1$ ?pq-origsite $=$ gscholar $\& c b l=18$ 750\&diss $=y$

Nairn, K. \& Kraftl, P. (2016). Introduction to Children and young people, space, place, and environment. In C. Skelton, K. Nairn \& P. Kraftl (Eds.), Space, place, and environment (pp. 1-24). Springer. https://doi.org/10.1007/978-981-287044-5_33 
Nordtømme, S. (2012). Place, space and materiality for pedagogy in a kindergarten. Education Inquiry, 3(3), 317-333. https://doi.org/10.3402/edui. v3i3.22037

Olsson, Å. (2017). Children's lived citizenship: A study on children's everyday knowledge of injury risks and safety. Childhood, 24(4). https://doi.org/10. $1177 / 0907568217718031$

Organisation for Economic Co-operation and Development (OECD). (2009). Creating effective teaching and learning environments. First results from Talis. Author. https://doi.org/10.1787/9789264068780-en

Organisation for Economic Co-operation and Development (OECD). (2017). The OECD handbook for innovative learning environments. Author. https://doi. org/10.1787/9789264277274-en

Pacini-Ketchabaw, V., Kind, S. \& Kocher, L. L. M. (2016). Encounters with materials in early childhood education. In Encounters with Materials in Early Childhood Education (1st Edition). Routledge. https://doi.org/10.4324/ 9781315743257

Palladino, M. \& Miller, J. (2015). The globalization of space: Foucault and heterotopia. In The globalization of space: Foucault and heterotopia (pp. 1-12). Routledge. https://doi.org/10.4324/9781315654188

Pardo, M. \& Opazo, M. J. (2019). Resisting schoolification from the classroom. Exploring the professional identity of early childhood teachers in Chile. Cultura y Educación, 31(1), 67-92. https://doi.org/10.1080/11356405.2018.1559490

Patterson, C. \& Kocher, L. (2018). Pedagogies for Children's perspectives. In Pedagogies for children's perspectives (Thinking A). Routdlege. https://doi. org/10.4324/9781351266840

Phillips, L. G. \& Moroney, K. (2017). Civic action and learning with a community of aboriginal Australian young children. Australasian Journal of Early Childhood, 42(4). https://doi.org/10.23965/AJEC.42.4.10

Pink, S. (2008). An urban tour: The sensory sociality of ethnographic place-making. Ethnography, 9(2). https://doi.org/10.1177/1466138108089467

Pink, S. (2012). Doing sensory ethnography. Sage. https://doi.org/10.4135/ 9781446249383

Pitsikali, A. \& Parnell, R. (2019). The public playground paradox: "Child's joy" or heterotopia of fear? Children's Geographies, 17(6), 719-731. https://doi.or g/10.1080/14733285.2019.1605046

Procter, L. \& Hackett, A. (2017). Playing with place in early childhood: An analysis of dark emotion and materiality in children's play. Contemporary Issues in Early Childhood, 18(2). https://doi.org/10.1177/1463949117714082

Programa de las Naciones Unidas para el Desarrollo (PNUD). (2017). Desiguales. Orígenes, cambios y desafíos de la brecha social en Chile. Santiago de Chile. Uqbar.

Pyyry, N. (2016). Learning with the city via enchantment: Photo-walks as creative encounters. Discourse, 37(1), 102-115. https://doi.org/10.1080/01596306. 2014.929841

Radford, G. P., Radford, M. L. \& Lingel, J. (2015). The library as heterotopia: Michel Foucault and the experience of library space. Journal of Documentation, 71(4). https://doi.org/10.1108/JD-01-2014-0006 
Rinaldi, C. (2012). Re-imagining childhood: The inspiration of Reggio Emilia education principles in South Australia. Adelaide Thinker in Residence.

Robson, K. \& Mastrangelo, S. (2018). Children's views of the learning environment: A study exploring the Reggio Emilia principle of the environment as the third teacher. Journal of Childhood Studies, 42(4), 1-16. https://doi. org/10.18357/jcs.v42i4.18100

Ryan, S. \& Grieshaber, S. (2005). Shifting from developmental to postmodern practices in early childhood teacher education. Journal of Teacher Education, 56, 34-45. https://doi.org/10.1177/0022487104272057

Shenk, D. (2015). The genius in all of us: New insights into genetics, talent, and IQ. Random House.

Shonkoff, J. P. (2010). Building a new biodevelopmental framework to guide the future of early childhood policy. Child Development, 81(1), 357-367. https:// doi.org/10.1111/j.1467-8624.2009.01399.x

Sounoglou, M. \& Michalopoulou, A. (2016). Early Childhood Education Curricula: Human Rights and Citizenship in Early Childhood Education. Journal of Education and Learning. https://doi.org/10.5539/jel.v6n2p53

St. Pierre, E. A. (2018). Writing post qualitative inquiry. Qualitative Inquiry, 24(9), 603-608. https://doi.org/10.1177/1077800417734567

St. Pierre, E. A. (2019). Post qualitative inquiry. In N. K. Denzin \& M. D. Giardina (Eds.), Qualitative inquiry in neoliberal times (pp. 37-47). Routledge. https:// doi.org/10.4324/9781315397788-3

Stephen, C. \& Gadda, A. (2017). Nurturing citizenship in the early years. University of Stirling.

Strong-Wilson, T. \& Ellis, J. (2007). Children and place: Reggio Emilia's environment as third teacher. Theory into Practice, 46(1), 40-47. https://doi. org/10.1207/s15430421tip4601_6

Sylva, K., Siraj-Blatchford, I., Taggart, B., Sammons, P., Melhuish, E., Elliot, K. \& Totsika, V. (2006). Capturing quality in early childhood through environmental rating scales. Early Childhood Research Quarterly, 21(1). https://doi. org/10.1016/j.ecresq.2006.01.003

Taylor, A. \& Richardson, C. (2005). Queering home corner. Contemporary Issues in Early Childhood, 6(2), 163-173. https://doi.org/10.2304/ciec.2005.6.2.6

Theobald, P. (2018). Teaching the commons: Place, pride, and the renewal of community. Taylor \& Francis. https://doi.org/10.4324/9780429496950

Thiel, J. J. (2015). "Bumblebee's in trouble!" Embodied literacies during imaginative superhero play. Language Arts, 93(1), 38-49. https://www.jstor.org/ stable/24577556

Warming, H. \& Fahnøe, K. (2017). Social work and lived citizenship. In Lived citizenship on the edge of society (pp. 1-22). Palgrave Macmillan. https://doi. org/10.1007/978-3-319-55068-8_1

Wild, C. (2011). Making creative spaces: The art and design classroom as a site of performativity. International Journal of Art and Design Education, 30(3), 423-432. https://doi.org/10.1111/j.1476-8070.2011.01722.x

Wood, J., Thall, T. \& Parnell, E. C. (2015). The move: Reggio Emilia-inspired teaching. Complicity: An International Journal of Complexity and Education, 12(1). https://doi.org/10.29173/cmplct24241 
Woolner, P., McCarter, S., Wall, K. \& Higgins, S. (2012). Changed learning through changed space: When can a participatory approach to the learning environment challenge preconceptions and alter practice? Improving Schools, 15(1). https://doi.org/10.1177/1365480211434796

Woolner, P., Thomas, U. \& Tiplady, L. (2018). Structural change from physical foundations: The role of the environment in enacting school change. Journal of Educational Change, 19(2), 223-242. https://doi.org/10.1007/s10833018-9317-4

Xu, P. (2020). Positioning children citizens: Exploring discourses in early childhood curricula in China and Aotearoa New Zealand. The New Zealand Annual Review of Education, 24, 58-74. https://doi.org/10.26686/nzaroe.v24i0.6324 